\title{
The Paradigm of Pluralism In Indonesia: Communal VS Legal State
}

\author{
Suci Flambonita \\ Faculty of Law, Universitas Sriwijaya, Palembang, Indonesia \\ suciflambonita@fh.unsri.ac.id, Orcid ID https://orcid.org/0000-0001-8056-6431
}

\begin{abstract}
Indonesia with all of its diversities in which law and culture live side by side and become part of state law regularity. Centralistic view contends that the only institution which plays role in creating social regularity is the country through the law formed and determined by the country. In its reality, there are many 'other forces' that do not come from the state such as customary law, religion law, habits, trade agreement across country and so on. Those forces also have the ability to regulate the community actions bound in it even sometimes the member or the community in the society prefers to obey the rules formed by their group compared to the state law regulations. The research method used was sociological approach with moral, ethic, and religious approach. Traditional communities are groups of individuals who live from generation to generation in a certain geographical territory and are bind by cultural identities, strong relationships with their indigenous land, regions, and natural resources. Their value system determines their economic, political, and legal institutions. Indigenous peoples are groups of individuals who live from generation to generation in a certain geographical territory and are bind by cultural identities, strong relationships with their indigenous land, regions, and natural resources. Their value system determines their economic, political, and legal institutions arranged by customary institutions that have the authority to govern.
\end{abstract}

Keywords. Pluralism, Law, Communal.

\section{Introduction}

Traditional communities are groups of individuals who live from generation to generation in a certain geographical territory and are bind by cultural identities, strong relationships with their indigenous land, regions, and natural resources. Their value system determines their economic, political, and legal institutions. Indigenous peoples are groups of individuals who live from generation to generation in a certain geographical territory and are bind by cultural identities, strong relationships with their indigenous land, regions, and natural resources. Their value system determines their economic, political, and legal institutions arranged by customary institutions that have the authority to govern the members. Based on the definitions, in this research the term indigenous peoples is more appropriate. Legal pluralism is a set of glasses that seeks to reconceptualize the relationship between 
law and the community. Legal pluralism also tries to identify the authenticity of legal phenomena operating in global scope

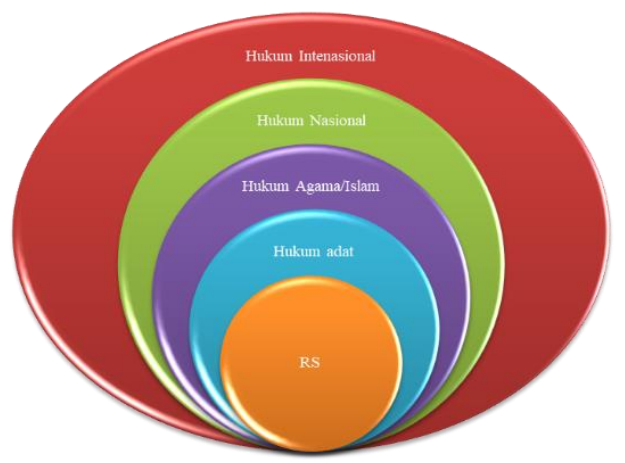

Harmonization attempts to ensure that the outputs of the nonstate justice system are consistent with the state system's core values. At the same time, the non-state justice system is incorporated and legitimatized to some extent. To support harmonization, states and international donors often fund activities to encourage nonstate justice practitioners to act in a manner consistent with state law in general. However, there is often at least tacit recognition that nonstate actors retain a significant degree of autonomy and independent legitimacy. Thus, there is a willingness to tolerate some normative differences in adjudication standards. As opposed to trying to get nonstate venues to act like state courts of first instance, there is a focus on changing the treatment of certain legal matters, for example, nonstate actors' treatment of women (CHOPRA, 2012). State judicial actors also frequently discriminate against women, but usually this is done in violation of state law rather than as a matter of accepted practice (CAMPBELL, 2016).

While the prevalence and endurance of nonstate justice mechanisms could be seen as an indictment of the need for state justice to underpin the rule of law, non-state justice mechanisms often have significant negative externalities. Nonstate legal orders frequently reflect cultural or religious norms unconcerned with basic human rights. Women and other vulnerable groups are particularly at risk when nonstate legal systems embrace overtly patriarchal ideals. These systems can also reflect significant bias toward powerful individuals and families, and the legal processes often lack core protections, such as procedural and substantive due process norms. As Waldorf highlights, nonstate "judicial" elites are neither independent nor impartial, and their discretionary rulings serve community harmony not individualized justice" (WALDORF, 2006). Furthermore, the relationship between state and non-state justice is often unclear, and cases may be resolved in different ways, encouraging forum shopping by parties, particularly those with more economic or political clout. The state system's predominance in itself does not guarantee a just outcome at a systemic level, as it could be a means for more effective despotism (KRYGIER, 2011). Although legal pluralists are unable to reach agreement about the "legal" in legal pluralism, they have shown that law can exist and operate without the state being a necessary condition (Woodman 1998; Beckmann 2002), and non-state laws can coexist in the same social field as state law in every society

The theory of legal pluralism is interpreted as the connecting line between various legal system in certain communities, including legal culture. This is what was captured by Werner Menski, a professor in law of the University of London during his research on legal comparison in Asian and African countries. He concluded that law enforcements in Asian and African countries are different from those on Western countries, particularly Europeans. European law enforcement is not significantly affected by non-legal elements such as morality, ethics, and religion. European nations are very comfortable with state law (Kherid, 2019).

The definition of pluralism is in the domain of socio-legal studies. Menski describes pluralism as a triangle consisting of natural law, state positivism, and socio-legal approach. The three elements shape legal pluralism, introduced by Menski in 2006. This legal pluralism triangle concept supports 
the legal system theory of Lawrence M. Friedman, i.e. legal structure, legal substance, and legal culture. In this legal culture does legal pluralism work. The work of legal pluralism in Indonesia's legal culture is influenced by local law values. Law can work effectively and be accepted by the community when the law does not confront the local law. In the context of Indonesia, the core of legal culture is Pancasila, which becomes the benchmark of legal structure's operation (Saptomo, 2012).

Leopold Posposil in his book The Anthropological Law (1971) proposed that the main source of law is not the state (as believed by positivism) but from human behavior and from laws that can accommodate people's pluralism. Similarly, Frederick Karl von Savigny perceives that good laws come from people's customs, habits, and desire materialized through representative institution so that the produced law can fulfil people's wants to meet their social lives (Saptomo, 2012).

In general, the greater the state's ability to offer a compelling and legitimate forum for dispute resolution worth emulating, the greater the prospects of successfully implementing a harmonization approach. Successful harmonization occurs most frequently in competitive-and especially cooperative-legal pluralism environments. Nevertheless, as long as nonstate actors retain a significant degree of autonomy, meaningful divergence with state policy remains possible. Thus, the structure and implications of legal pluralism must be considered when creating and implementing policy. The "legal" in legal pluralism and the "law" in rule of law are evidence that the two are essentially linked. At the root of their theoretical formulations and practical applications, legal pluralism and rule of law share the idea of law and legality as a common theme. As a result, legal pluralism and rule of law are linked through the instrumentality of law and its institutional frameworks. Before exploring the relationship between legal pluralism and rule of law, it is necessary to consider the meaning and contents of rule of law to have a clear sense of the concept as used in this article. (John, 2005)

\section{Result and Discussion}

The first definition is formal and goes like this: "rule of law means that government officials and citizens are bound by and abide by the law" (Tamanaha, 2011). The second definition has a substantive content and sees rule of law as a principle of governance in which all persons, institutions and entities, public and private, including the State itself, are accountable to laws that are publicly promulgated, equally enforced and independently adjudicated, and which are consistent with international human rights norms and standards. It requires, as well, measures to ensure adherence to the principles of supremacy of law, equality before the law, accountability to the law, fairness in the application of the law, separation of powers, participation in decision-making, legal certainty, avoidance of arbitrariness and procedural and legal transparency (United Nations 2004, 4)

Indeed, legal pluralism and the rule of law have complex relationships. Both types of legal pluralism can be compatible with or diverge from rule of law conceptions. For instance, consider classic legal pluralism. Customary and sharia laws not only empower traditional and religious authorities, but also limit their powers. In addition, these laws are publicly known, certain, and have a general application in the respective communities (Elias 1956; Anderson 2007). Moreover, these laws are clear, short, and well known by large segments of the community (Fenrich, Galizzi, and Higgins 2011). As explained beforehand, legal pluralism can be said becoming the answer towards the weakness found in the point of view of national legal system in Indonesia which tends to be centralistic.

As the new social movement in the context of multiculturalism, fighting for socioeconomic and natural resource redistribution is as important as providing spaces to foster cultural struggle in terms of fighting discrimination against indigenous peoples (Suci Flambonita, 2010).

Various conditions sufficiently describe the weakness and criticism towards legal pluralism as discussed beforehand that it opens the norm conflict opportunity which in the end causing legal uncertainty that somehow is the important principle in legal enforcement. Beside that, the criticism at once the substantial question about legal pluralism appears from the the problem description namely if 
legal pluralism provides practical solution for legal problem solving in Indonesia's communal community because as a system based on communal, Indonesia's community with various elements of life and develop in the community which then collided with the positive law in Indonesia. Legal pluralism indeed does not immediately solve the problem appearing in the community.

However, legal pluralism presents to give the new understanding to the legal practitioners, the state country actors (the legislators) and the community in general that beside the state law, there are other legal systems existed in the first place in the community and these legal systems interact with the state law and even compete to each other. On the other hand, legal pluralism gives explanation towards the presence of social order which is not part of state law regularity. Centralistic view contends that the only institution which plays roles in creating social regularity is the country through the law formed and determined by the country. In its reality, there are many 'other forces' that do not come from the country such as customary law, religious law, habits, trade agreement across country, and so on. These forces also have capability to regulate the community actions bound in it even sometimes the member or the community in the society prefers to obey the rules formed by their group compared to the state law.

Traditional communities are groups of individuals who live from generation to generation in a certain geographical territory and are bind by cultural identities, strong relationships with their indigenous land, regions, and natural resources. Their value system determines their economic, political, and legal institutions. Indigenous peoples are groups of individuals who live from generation to generation in a certain geographical territory and are bind by cultural identities, strong relationships with their indigenous land, regions, and natural resources. Their value system determines their economic, political, and legal institutions arranged by customary institutions that have the authority to govern the members. Based on the definitions, in this research the term indigenous peoples is more appropriate.

Legal pluralism is a set of glasses that seeks to reconceptualize the relationship between law and the community. Legal pluralism also tries to identify the authenticity of legal phenomena operating in global scope. Therefore, based on the posture of the related concept, legal pluralism is a quite bulky discussion area (Rahardjo, 1979). Communities with definite social system provides guidelines for their members concerning with how the relations among them should be made. Statements about the distribution of natural resource in the community can be conceptionally found in rules that are basic in nature. Whenever the law decides a distribution, the measure will be determined by the relation between law and justice. According to Aristotle, justice is a political policy whose rules become the foundation of state rules, and the rules are the measurement of rights.

According to Griffiths, there are two types of legal pluralism: strong and weak legal pluralism. The strong legal pluralism is the condition where each of the different legal systems is autonomous, and its existence does not depend on state law. If the existence of legal pluralism depends on the state law, the condition is called weal legal pluralism (Griffiths, 1986). In other words, legal pluralism is strong when there is a situation where the various legal systems live equally without domination by either of them. Individuals or groups living in certain social spaces or territories are free to choose one of the laws and free to combine the various systems in living their daily lives and resolving disputes. The weak legal pluralism occurs when one of the legal systems is superior than others. Here individuals or groups use one of the system due to pressure. The various concepts were developed by Simarmata. Pluralism also finds relations between the various legal system; the might be in forms of diffusion, competition, or cooperation. For example, state law does not always deny customary law. Instead, it admits and accommodates the existence of customary law, and vice versa. Legal pluralism does not only develop in terms of territories or study object but also develop in another way, i.e. refining and sharpening itself. Several similar thoughts are (1) strong legal pluralism and weak legal pluralism, (2) mapping of law, and (3) critical legal pluralism (Simarmata, 2005). While the prevalence and endurance of nonstate justice mechanisms could be seen as an indictment of the need for state justice to underpin the rule of law, non-state justice mechanisms often have significant 
negative externalities. Nonstate legal orders frequently reflect cultural or religious norms unconcerned with basic human rights. Women and other vulnerable groups are particularly at risk when nonstate legal systems embrace overtly patriarchal ideals. These systems can also reflect significant bias toward powerful individuals and families, and the legal processes often lack core protections, such as procedural and substantive due process norms. As Waldorf highlights, nonstate "judicial" elites are neither independent nor impartial, and their discretionary rulings serve community harmony not individualized justice" (WALDORF, 2006).

Furthermore, the relationship between state and non-state justice is often unclear, and cases may be resolved in different ways, encouraging forum shopping by parties, particularly those with more economic or political clout. The state system's predominance in itself does not guarantee a just outcome at a systemic level, as it could be a means for more effective despotism (KRYGIER, 2011). Although legal pluralists are unable to reach agreement about the "legal" in legal pluralism, they have shown that law can exist and operate without the state being a necessary condition (Woodman 1998; Beckmann 2002), and non-state laws can coexist in the same social field as state law in every society

The theory of legal pluralism is interpreted as the connecting line between various legal system in certain communities, including legal culture. This is what was captured by Werner Menski, a professor in law of the University of London during his research on legal comparison in Asian and African countries. He concluded that law enforcements in Asian and African countries are different from those on Western countries, particularly Europeans. European law enforcement is not significantly affected by non-legal elements such as morality, ethics, and religion. European nations are very comfortable with state law (Kherid, 2019).

\section{Conclusion}

Nonstate legal orders frequently reflect cultural or religious norms unconcerned with basic human rights. Women and other vulnerable groups are particularly at risk when nonstate legal systems embrace overtly patriarchal ideals. These systems can also reflect significant bias toward powerful individuals and families, and the legal processes often lack core protections, such as procedural and substantive due process norms. Traditional communities are groups of individuals who live from generation to generation in a certain geographical territory and are bind by cultural identities, strong relationships with their indigenous land, regions, and natural resources. Their value system determines their economic, political, and legal institutions. Indigenous peoples are groups of individuals who live from generation to generation in a certain geographical territory and are bind by cultural identities, strong relationships with their indigenous land, regions, and natural resources. Legal pluralism does not only develop in terms of territories or study object but also develop in another way, i.e. refining and sharpening itself. Several similar thoughts are (1) strong legal pluralism and weak legal pluralism, (2) mapping of law, and (3) critical legal pluralism. Legal pluralism paradigm emerges to unravel legal symptoms and phenomena in the same social space. Therefore, to unravel this concept we need to let legal culture live and grow in the pluralistic Indonesia because essentially the main source of law is not the state (as believed by positivism) but human behavior and laws that can accommodate people's pluralism, i.e. customary law which grows and develops well without the use of state law

\section{References}

[1] Benda Beckmann, F. The Moving Law: The Review of Legal Anthropology. Jakarta: Yayasan Obor Indonesia. 2009

[2] CAMPBELL, M. A. Legal Pluralism andWomen's Rights after Conflict: The Role of Cedaw. Columbian Human Rights Review, 2016, 46-112.

[3] CHOPRA, T. A. Access to Justice and Legal Pluralism in Fragile States: The Case Rights. Hague Journal on the Rule of Law, 4(2), 337-358. (2012)

[4] FEARON, J. D. Neotrusteeship and the Problem of Weak States. International Security, 28(4), 5-43. (2004.). 
[5] Griffiths, J. What is Legal Pluralism. Journal of Legal Pluralism and Unoficial Law, $24,1$. 1986.

[6] Kherid, M. N. PLURALISM JUSTICE SYSTEM. Legal Problems, 48(4), 385-392. (2019)

[7] KRYGIER, M. "Approaching the Rule of Law." The Rule of Law in Afghanistan: Missing in Inaction. 15-34. (2011).

[8] Rahardjo, S. Legal Culture in Legal Problems in Indonesia. The Board of National Law Guidance, National Law Seminar The IV, The Board of National Law Guidance, Jakarta. (1979).

[9] Suci Flambonita, Albar Sentosa S, Hamonangan Albariansyah, The Principles of Customary Law. Palembang: Universitas Sriwijaya Press. (2010)

[10] WALDORF, L. "Mass Justice for Mass Atrocity: Rethinking Local Justice as Transitional Justice.". Temple Law Review , 79(1), 1-87. (2006).

[11] Warman, K. The Position of Customary Law in Development Reality of Agrarian Law in Indonesia. Constitution Journal, 6(4), 25. (2009).

[12] Woodman, G. R. "Is it possible to make legal map?", Legal Pluralism: An Interdisciplinary Approach. Jakarta: Ford Foundation - HuMa. (2005). 